\title{
Requests and donations to the College
}

\section{Morris Markowe Public Education Prize}

The College is particularly indebted to the family of Dr Morris Markowe for endowing the College with sufficient funds to establish the Morris Markowe Public Education Prize. This Prize will be awarded annually for an article on a psychiatric topic of approximately 1000 words, suitable for publication in a regional newspaper, lay journal, the paramedical press or a general practitioner's magazine.
Dr and Mrs D. Jolley

Dr and Mrs Jolley have generously donated a splendid radio cassette to be used in the College for educational purposes.

\section{Mrs M. Clouston}

The College is very grateful to Mrs Mary Clouston who has donated $£ 21,000$ worth of stocks and shares to fund future College activities.

\section{Obituary}

\author{
Editor: Henry R. Rollin
}

William Vaughan Adams Erskine, formerly Consultant Psychiatrist, Garlands Hospital, Carlisle

Doctor Erskine, who died on 22 March 1989 at the age of 76, was born in Nottingham on 4 July 1912, the eldest child of Dr W. J. A. Erskine, then Deputy Medical Superintendent of Mapperley Hospital. In 1916 the family moved to the Isle of Wight where his father had been appointed Medical Superintendent of Whitecroft Hospital.

Vaughan Erskine was educated at Epsom College. While at Epsom and on the Island, he acquired an abiding knowledge of the countryside and enjoyed the pursuits that it offered throughout his life.

He began his medical training at Liverpool University but later transferred to Edinburgh where he qualified LRCP, LRCS, Ed LRFPS, Glas. in 1938.

After a period as a houseman at hospitals on the Kent coast he entered the Mental Health Service at Upton Mental Hospital, Cheshire. Shortly after the outbreak of the 1939-1945 War he joined the RAMC where he served in a Field Ambulance. During this time he developed renal disease necessitating major surgery. He was subsequently invalided from the Service. It was from his convalescent bed on the lawns at The Orchard, Formby, that he learned the art of fly casting, an angling technique at which he subsequently excelled and which remained a life long passion. He was also an excellent shot and a keen naturalist.

He returned to work at the Deva Hospital (now known as the Countess of Chester Hospital) until his appointment as consultant to Garlands Hospital, Carlisle in 1951.

Throughout his professional career he applied himself assiduously to the treatment of his patients, many of whom he knew by their Christian names and who benefited greatly from his confident and reassuring manner. He eagerly embraced some of the new techniques being developed in the practice of psychiatry in the 1960s and 1970s while continuing to employ his well tested and successful therapies.

He was a respected and effective teacher of nurses and junior medical staff, and advised in the compilation of a dictionary for nurses.

With the advent of a form of Tripartite administration at Garlands Hospital in 1963 he enthusiastically took part and developed good relationships with other management personnel. Throughout these changing times he never lost sight of the need to keep the welfare of his patients paramount.

He was elected a Foundation Fellow of the College at its inception.

Vaughan Erskine was a tolerant, affable, caring and kindly man whose talent as a raconteur was enjoyed by a large circle of friends. 